\title{
Evaluation of soil physical properties as influenced by various green manuring legumes and phosphorus fertilization under rain fed conditions
}

\author{
${ }^{1}$ M. I. Sultani, ${ }^{1}$ M. A. Gill, ${ }^{1}$ M. M. Anwar, ${ }^{2 *}$ M. Athar \\ ${ }^{1}$ Institute of Natural Resources and Environmental Sciences,National Agricultural Research Center, Islamabad, Pakistan \\ ${ }^{2}$ California Department of Food and Agriculture, 3288 Meadowview Road,Sacramento, CA., USA
}

Received 6 July 2006; revised 14 August 2006; accepted 18 September 2006; available online 1 January 2007

\begin{abstract}
A field experiment was conducted under rainfed environment of Pothowar region of Pakistan to assess physical properties of soil as influenced by various green manure legumes (sesbania, cluster bean and rice bean) and different $\mathrm{P}$ levels $\left(0,30,60,90 \mathrm{~kg} \mathrm{P}_{2} \mathrm{O}_{5}\right.$ /ha). Highest fresh biomass was observed in sesbania (23 t/ha) followed by cluster bean (19 t/ha) and lowest in rice bean (17 t/ha). Maximum crude protein content was found in sesbania (17\%) followed by rice bean (10\%) and cluster bean (8\%). Green manuring crops, on average reduced soil bulk density (5\%), enhanced total porosity (8\%), and macropores and large mesopores (28\%). Maximum reduction (7\%) in soil bulk density, and an increase $(11 \%)$ in total soil porosity and available water $(17 \%)$ was observed in plots where sesbania was incorporated as green manuring crop. The order of effectiveness in improving bulk density, macro and mesopores was sesbania $>$ cluster bean $>$ rice bean. Sesbania produced greater number of macro and large mesopores about $41 \%$ increase over control followed by cluster bean (29\%) and rice bean (16\%). Phosphorus application showed meager positive impact on various soil physical properties but did not significantly increased porosity or reduced bulk density. Significant differences in volume fraction in pore space suggest that pore space on a volume basis was much higher in sesbania-amended soil than in other treatments.
\end{abstract}

Key words: Green manuring legumes, phosphorus application, soil physical properties, rainfed environments

\section{INTRODUCTION}

Green manuring has been known to improve soil fertility. The benefits of green manuring are multifold. It increases soil organic matter, available nitrogen, concentration of nutrients near the soil surface in available form, and reduces the $\mathrm{N}$ losses through leaching and soil erosion. Increases organic matter in soil as a result of green manure improves soil physical properties by increasing the distribution and stability of soil aggregates and decreasing soil bulk density (McRae and Mehuys, 1988). Vegetative cover prevents the build-up of the aggregates, which could lead to the formation of surface crusts that reduce water infiltration. Green manuring is the most important way to influence topsoil. The vegetative cover reduces runoff as well as the concentration and the size of the transported sediment particles and thus, the rates of loss of both soil and moisture. It also influences the soil moisture and temperature dynamics. The reduction

\footnotetext{
*Corresponding author, Email: atariq@cdfa.ca.gov

Tel: +916 262 0855, Fax: +916262 2059
}

of moisture losses can be attributed to the combination of several factors (Shukla, et al. 2004): (i) a significant reduction in the rate of surface evaporation and surface runoff, and (ii) increases in infiltration rates and moisture retention capacity of the soil The soil physical properties that are affected by incorporation of the green manure include the structure, moisture retention capacity, consistency and density. Other properties such as the porosity, aeration, conductivity, hydraulics and infiltration are allied to the modifications to the soil structure. Post-harvest decaying roots significantly increase macropores in soil. This effect depends on climatic factors and the soil characteristics. Both legumes and non-legumes are used as green manures. However, legumes are superior green manure crops as they fix atmospheric nitrogen and add it to the soil nitrogen pool (Carlson and Huss-Danell, 2003; Mayer, et al., 2003). Legumes are known to improve soil fertility by adding much needed organic matter in the soils. Use of annual forage legumes such as sesbania, cluster 
bean and/or rice bean as green manures, can improve soil fertility and can help increase the productivity of the succeeding crop (Carlsson and Huss-Danell, 2003). These forage legumes could be included in the rainfed farming system of the Pothowar region (Pakistan) to improve soil fertility and increase crop productivity. The present study was thus conducted to evaluate the green manuring effect of forage legumes and phosphorus fertilization on the physical properties of the soil under rainfed environment of the Pothowar region.

\section{MATERIALS AND METHODS}

A field experiment was conducted during June 2002 to May 2003 at the experimental area of the National Agricultural Research Center, Islamabad, Pakistan. The Center is located in the Pothowar region in a subtropical, sub humid continental highland climatic zone characterized by hot long summers and cold winters. Soils of the area are inceptisol and loess in nature, slightly alkaline with $\mathrm{pH} 8.2$ and low in organic matter $(0.5 \%)$. The mean annual rainfall is $1000 \mathrm{~mm}, 70 \%$ of which occur during the monsoon (July to September) while the rest is received during the remaining months of the year. Metrological data for rainfall and temperature during experimental period are given in Figs. 1 and 2. The experiment was conducted as a randomized complete block design with two factors and four replications. The factors used were green manures legumes and phosphorus fertilization. Three legumes \{Sesbans, Sesbania aculeata (L.); rice bean, Vigna umbellate (Thunb.), cluster bean, Cyamopsis tetragonaloba (L.) \} were used as green manure crops. There was a combination of 16 treatments consisting of a fallow soil and three green manure legumes each with four phosphorus fertilization treatments consisting of $0,30,60$ and $90 \mathrm{~kg} /$ ha applied as $\mathrm{P}_{2} \mathrm{O}_{5}$. The land was plowed with double disc to prepare a suitable seed bed. The legumes were sown with a hand drill at a row distance of $40 \mathrm{~cm}$. The seeding rate was $50 \mathrm{~kg} / \mathrm{ha}$ for sesbania and cluster bean and $80 \mathrm{~kg} /$ ha for rice bean. The tender stem and plants of these forage legumes were manually harvested at blooming stage 60 days after their establishment, and were later chopped and incorporated into the soil by rotavator. Soil samples from two depths $(0-15$ and $15-30 \mathrm{~cm})$ were taken before and after incorporation of these legumes from each plot at random using double cylinder core samplers with sample holder (inner cylinder) diameter and height of $50 \mathrm{~mm}$ high (Black and Hartge, 1986). The sampler was pressed vertically into the soil surface enough to fill the sampler, but not so far to compress the soil in the compound space of the sampler. The sampler and its contents were carefully removed to preserve the natural structure and packing of the soil as best as possible. The two cylinders were sorted, retaining the undisturbed soil in the inner cylinder. The soil extending beyond each end of the sample holder was trimmed to flush with a straight edged knife. The soil sample volume was thus established to be the same as the volume of the sampler holder. The soil cores were wrapped in paper, transported and safely stored in the laboratory safely. Crude protein content of these forage legumes at harvest was calculated from total nitrogen of plants as determined by Kjeldahl method (Nelson and Sommers, 1980).

\section{Bulk density}

The soil was transferred from the sample holders of core sampler to a container and placed in an oven at $105^{\circ} \mathrm{C}$, and dried to constant weight. The weight of soil was recorded and bulk density was calculated by the formula of Black and Hartge, 1986.

Bulk Density $(\rho)=\frac{\text { Oven dry weight soil }}{\text { Sample volume }}$

\section{Total Porosity}

Total porosity of the soil was calculated from bulk density assuming a particle density of $2.65 \mathrm{mg} / \mathrm{m}^{3}$ with the following formula:

\section{Total Porosity $=1-\frac{\text { Bulk density }}{\text { Particle density }}$ \\ Available water and water retention}

The core samples were placed on smoothened wet sand and kept overnight. Four pieces were cut from each core and placed on pre-wetted plates having appropriate bubbling pressure. Soil water retention was determined, at lower suction, using a fine-sand tension tube with a hanging water column and at higher suction using pressure plate apparatus. Pore size distribution was calculated from the water release curve, and equivalent radius was determined by assuming cylindrical pores. Water was removed from a pore of a given radius when suction was exerted on that water which was greater than the forces acting to retain the water in the pore. The smallest drained pore neck radius 
$\mathrm{r}$ for a particular soil water or suction $(\mathrm{h})$ was calculated using the soil water capillary model (Klute, 1986).

$$
r=\frac{2 \gamma \operatorname{Cos} \Phi}{h g \rho w}
$$

Where $\gamma$ is the surface tension of water $\left(72.75 \times 10^{-3}\right.$ $\mathrm{N} / \mathrm{m}), \phi$ is the contact angle between water and solid (the contact angle is usually considered zero and Cos $\phi=1), \rho w$ is the density of the water $\left(988.2 \mathrm{~kg} / \mathrm{m}^{3}\right.$ at 20 $\left.{ }^{\circ} \mathrm{C}\right)$, and $g$ is the acceleration due to gravity $(9.8 \mathrm{~m} / \mathrm{s})$. The different parameters depend on temperature; at 20 ${ }^{\circ} \mathrm{C}$, (with appropriate changes in units) the equation may be written as

$$
\gamma=\frac{0.149}{h}
$$

Where $h$ is expressed in $\mathrm{cm}$ of water and $\gamma$ in $\mathrm{cm}$. Water retention and available water was determined successively at $-0.1,-5$ and $-15 \mathrm{MPa}$ using a pressure plate apparatus (Klute, 1986). Two years data of both the experiments were combined to get broad based reliable results. Data were subjected to statistical analysis using single factor randomized complete block design.

\section{RESULTS}

Effect of P levels on total biomass production

Application of phosphorus at various levels in loess soils of Pothowar had significant effect on fresh weight of the three green manuring legume species. Highest fresh biomass was observed in sesbania (23 $\left.\mathrm{t} \mathrm{ha}^{-1}\right)$ and lowest in rice bean $\left(17 \mathrm{tha}^{-1}\right)$ that was $35 \%$ less than sesbania. Cluster bean produced fresh biomass $\left(19 \mathrm{t} \mathrm{ha}^{-1}\right)$ that was $15 \%$ higher than rice bean. Maximum crude protein content was found in sesbania (17\%) followed by rice bean $(10 \%)$ and cluster bean $(8 \%)$. Fresh biomass production increased with increased P-fertilization in various green manuring legumes as examined individually in these experiments.

\section{Residual effect of green manures and P fertilization}

The biomass production of various green manure crops for following year was comparatively better than preceding year for each legume species and at each level of $\mathrm{P}$ application. Overall 3\% improvement was observed which might be due to integrated residual effect of previous green manuring legume and $\mathrm{P}$ fertilization. Though the difference was statistically non-significant, it could have great ecological importance. Considerable improvement could be expected within a few years if such little improvement continues unabated year after year.

\section{Effect of green manuring legumes and P levels on physical properties of soil}

Considerable influence of green manuring crops on physical properties of the soil was noticed as shown in Figs. 3-7. Green manuring on the average reduced soil bulk density by $5 \%$ and enhanced total porosity by $8 \%$ (Fig. 3). Maximum reduction of $7 \%$ in soil bulk density and an increase of $11 \%$ in total soil porosity were observed in plots where sesbania was incorporated as green manuring crop (Fig. 4). The order of effectiveness in improving bulk density was sesbania $>$ cluster bean $>$ rice bean $>$ control treatment. The effect of green manuring legumes especially sesbania was more pronounced at $0-15 \mathrm{~cm}$ than $15-30$ $\mathrm{cm}$ depth of soil. P application did not contribute significantly in the reduction of bulk density but with $90 \mathrm{~kg} \mathrm{P} / \mathrm{ha}$ the differences between green manuring legume treatments were more obvious at the surface soil. The observed decrease in bulk density was attributed to a significant increase of $8 \%$ in total porosity of soil under green manuring amendments. Maximum increase in total porosity was observed in surface soil where sesbania was incorporated as green manuring crop. The order of effectiveness of green manuring treatments improving total porosity of soil was sesbania $>$ cluster bean $>$ rice bean $>$ control. It was observed that green manuring crops on the average enhanced macropores $(>15 \mu \mathrm{m})$ and larger mesopores of size $(15-0.3 \mu \mathrm{m})$ up to $28 \%$. Sesbania was able to produce greater number of macropores $(>15 \mu \mathrm{m})$ and larger mesopores $(15-0.3 \mu \mathrm{m})$ in the surface soil which accounted for the about $41 \%$ increase over the control whereas the pore increase was $29 \%$ in cluster bean and $16 \%$ in rice bean. There was no significant change in other pore size classes such as macropores, smaller mesopores $(0.3-0.1 \mu \mathrm{m})$ and micropores $(<0.1 \mu \mathrm{m})$. This was likely due to the addition of organic matter and extensive root penetration to deeper layers. Similar observations were made by Gupta and Larson (1979) and Hill and Cruse (1985). Soil water retention was significantly influenced by $5 \%$ green manuring crops (Fig. 5). Soil under sesbania retained $7 \%$ more moisture than control 
at a metrics potential of -10 MPa whereas cluster bean resulted in 5\% greater moisture retention than the control (Fig. 6-a). It was observed that soil under sesbania retained the greatest volume of water followed by cluster bean and rice bean. Reduced tilled soil generally retained a significantly larger quantity of water than conventionally tilled soil. Green manuring substantially increased the amount of available water to plants by $17 \%$ than the control. This effect was more pronounced in the surface soil than in the sub-soil (Fig. 6-b). Soil with sesbania as green manure had maximum plant-available-water that was $23 \%$ than the control. P application has no effect on plant-available-water content of soil (Figs. 6-a, b). Green manuring in general increased macro and larger mesopores by $31 \%$. Sesbania was more effective in producing greater number of macropores and larger mesopores $(15-1.5 \mu \mathrm{m})$ in the surface soil by about $47 \%$ increase over control, whereas positive influence of cluster bean and rice bean was $35 \%$ and $21 \%$, respectively (Figs. $7-a, b$ ). There was no significant variation in pores of other size classes. Soil water retention was significantly $(\mathrm{P}=0.05)$ affected by $6 \%$ in green manuring crops. Soil under sesbania retained $9 \%$ more moisture over control followed by cluster bean (5\%) and rice bean (3\%). Green manuring significantly $(\mathrm{P}=0.05)$ increased the availability of water by $15 \%$ to plants by enhancing water retention of water in the soil. Sesbania as green manuring again had significantly $(\mathrm{P}=0.05)$ greater plant available water that was $18 \%$ higher than the control, whereas cluster bean and rice bean did not show any effect on plant-available water. Sesbania has deeper root system which helps produce greater number of macropores.

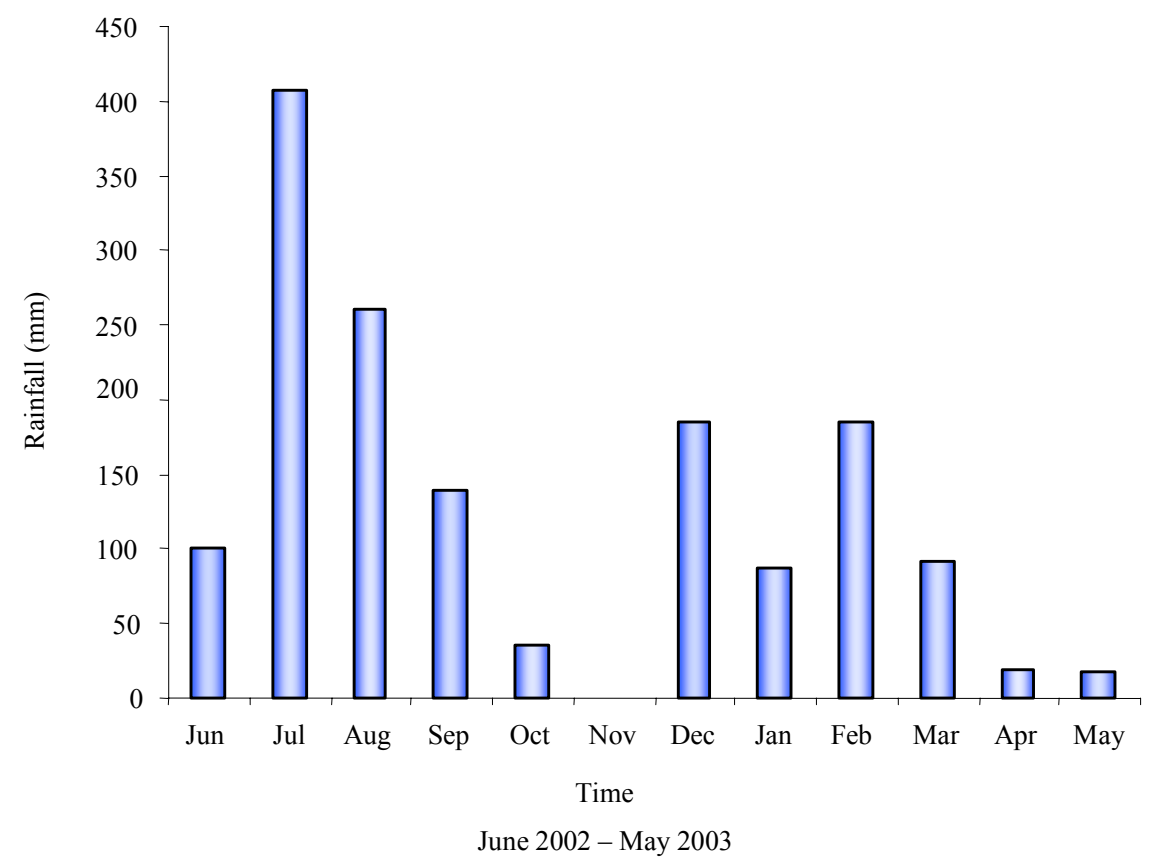

Fig. 1: Rainfall during the experimental period 2002-2003 


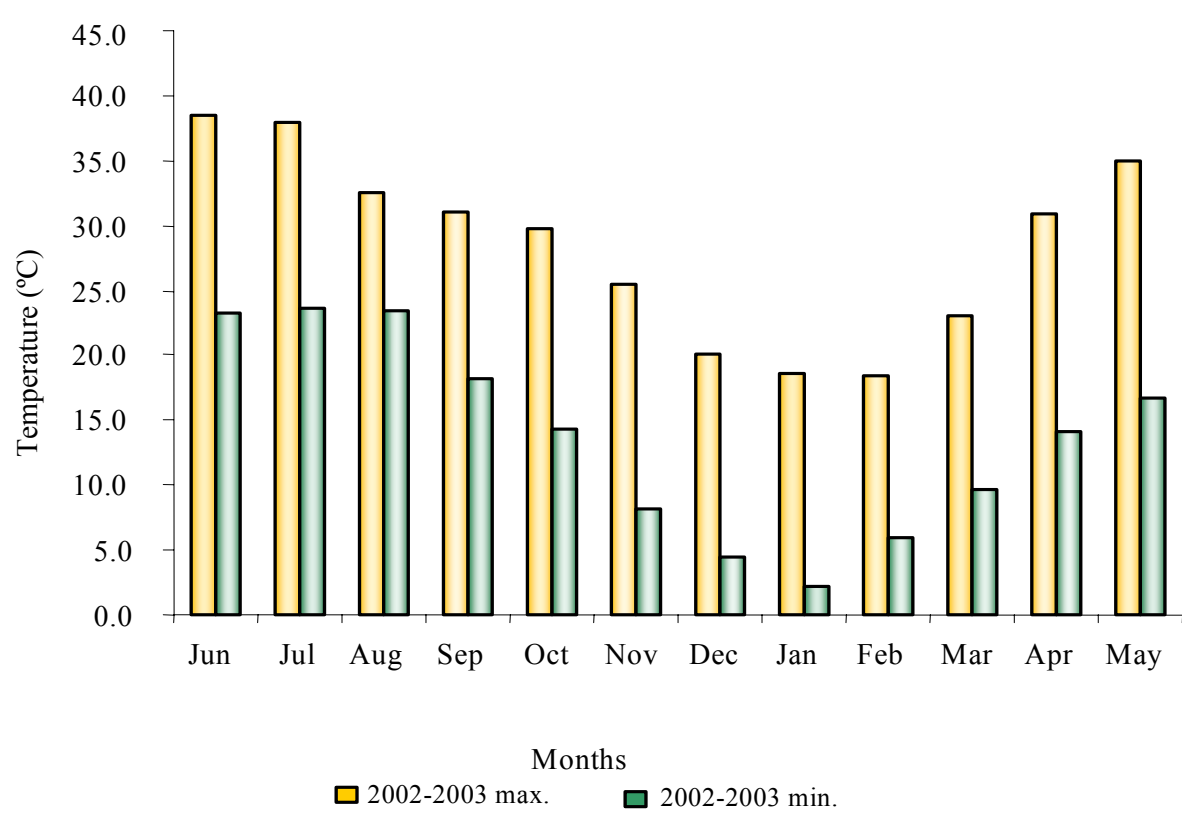

Fig. 2: Temperatures $\left({ }^{\circ} \mathrm{C}\right)$ regime during the experimental period 2002-2003

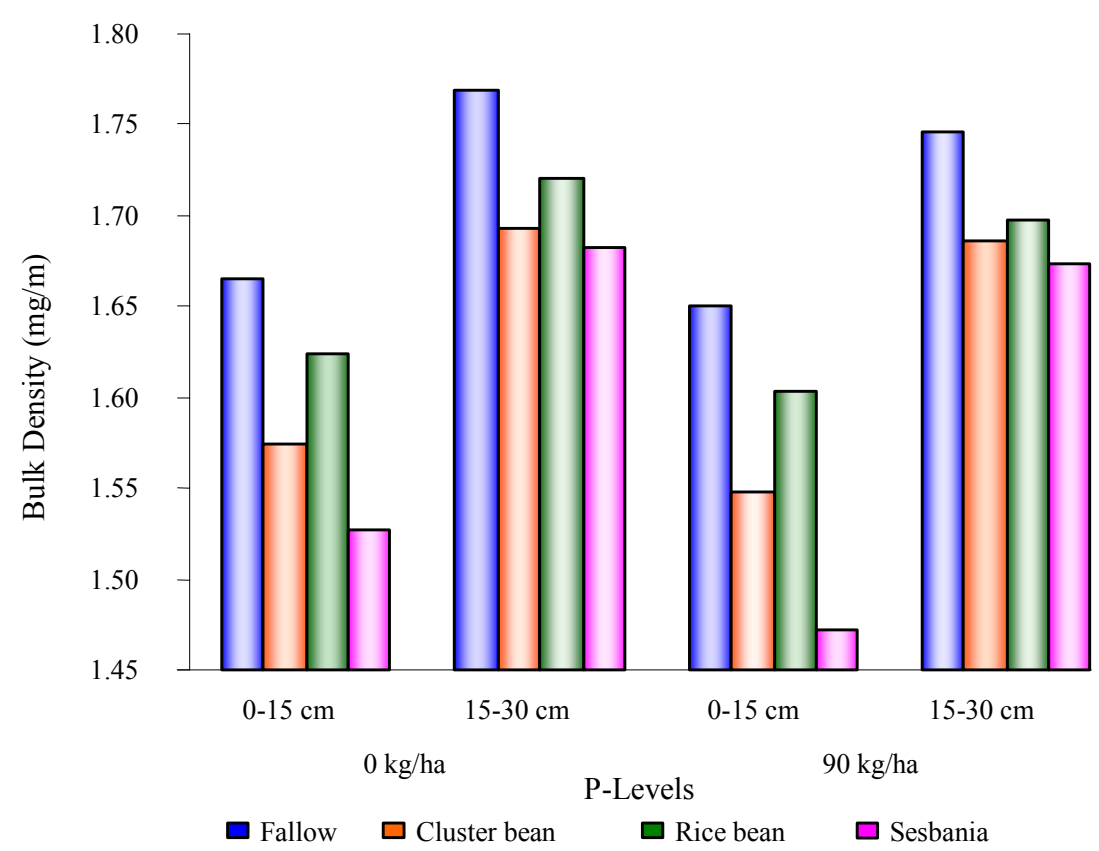

Fig. 3: Effect of green manuring legumes and P-fertilization on bulk density of soil 


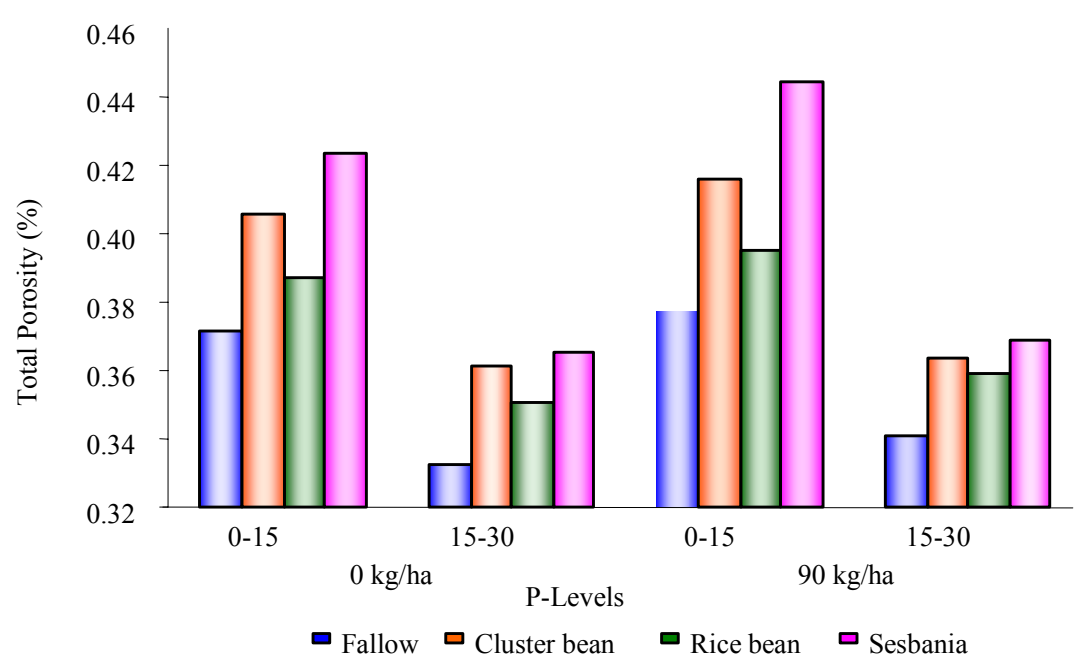

Fig. 4: Effect of green manuring legumes and P-fertilization on total porosity of soil

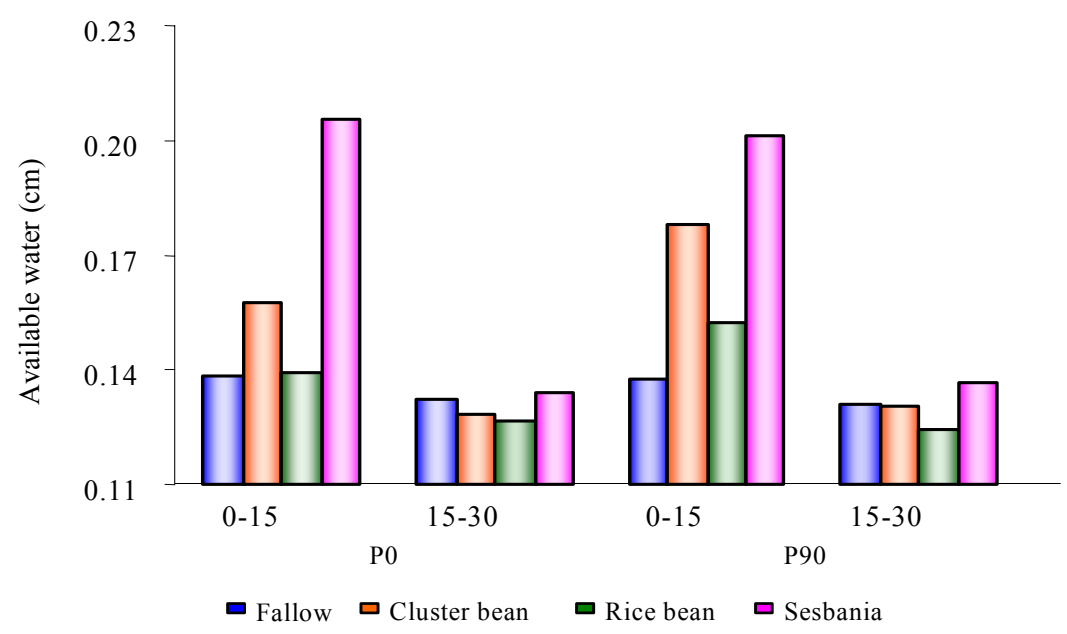

Fig. 5: Effect of green manuring legumes and P-fertilization on available water contents of soil

\section{DISCUSSION AND CONCLUSION}

Sustainable agricultural management practices are known to influence soil physical properties to maintain functional capacity of soil for crop growth (Ekwue, 1990; Islam and Weil, 2000-a; Min, et al,. 2003; Scott, et al., 1994). Phosphorus fertilization showed mild positive effect on various physical properties but did not contribute significantly in reducing bulk density or increasing porosity. No significant effect on soil water contents or on available water could be observed in this experiment. A significant decrease in bulk density with an associated increase in total porosity of soil under sesbania is probably related to greater amount of organic matter deposition and loosening of soil by root action (Haynes, 2000; Lampurlanes and CanteroMartinez, 2003). Bulk density is inversely related to total porosity, which provides a measure of the porous space left in the soil for air and water movement (Min et al., 2003; Tester, 1990). Lower bulk density implies greater pore space and improved aeration, developing a suitable environment for biological activity (Islam and Weil, 2000-b; Min, et al., 2003; Werner, 1997). Green manuring crops, like sesbania specifically influence soil structural properties by enmeshing soil primary particles and microaggregates into macroaggregation through direct physical action of roots, and production of cementing agents from enhanced microbial activities. 


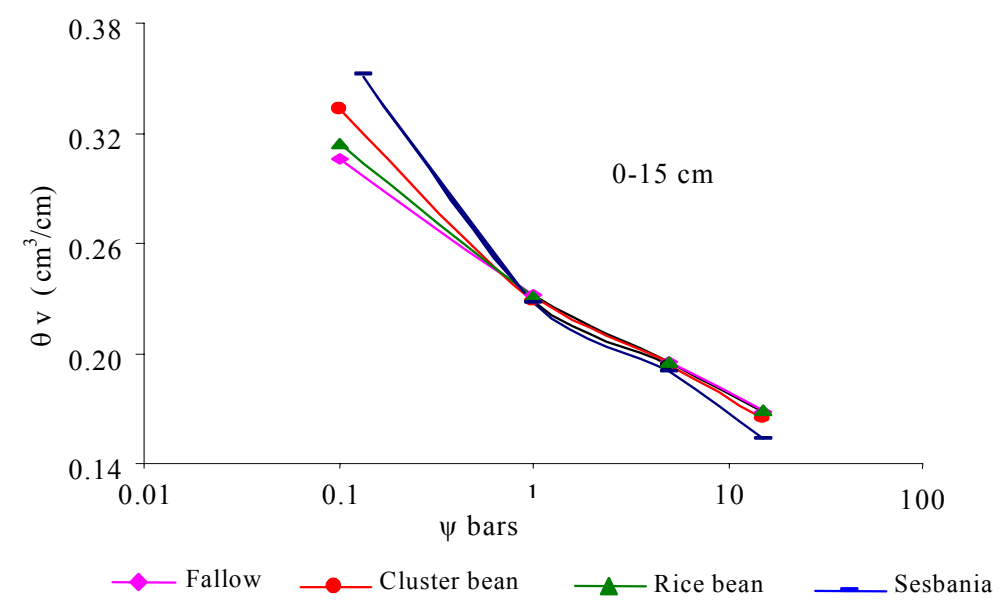

Fig. 6-a: Effect of green manuring legumes and P-fertilization on water retention characteristics of soil $(0-15 \mathrm{~cm})$

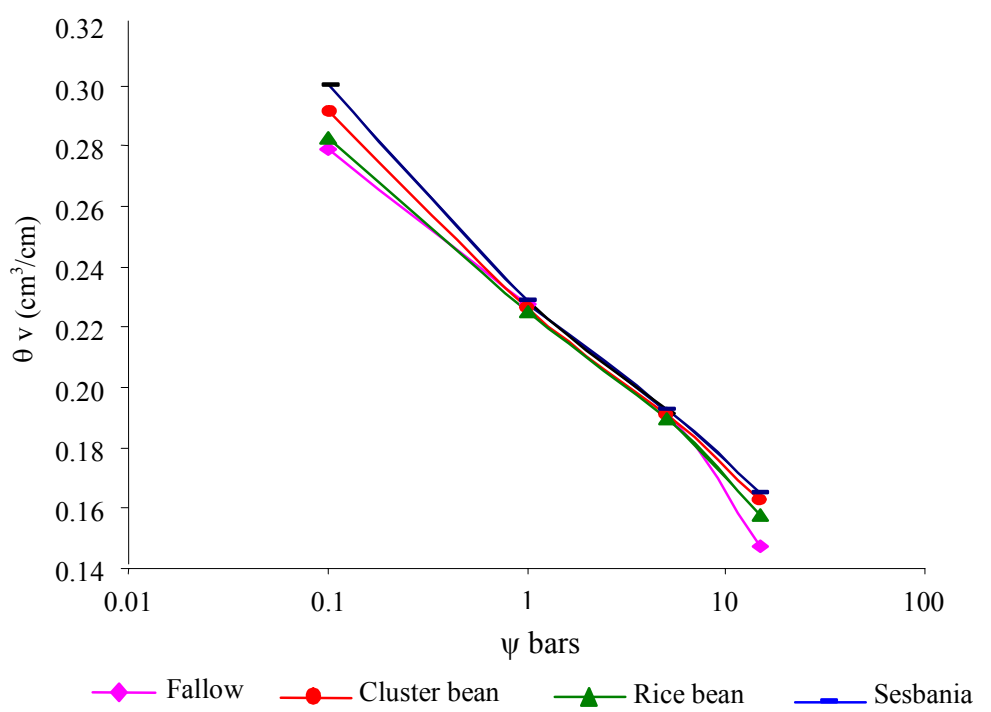

Fig. 6-b: Effect of green manuring legumes and P-fertilization on water retention characteristics of soil $(15-30 \mathrm{~cm})$

These aggregation processes and properties may reduce soil bulk density and increase porosity with greater water retention and transmission capacities (Goldhamer, et al., 1994; Hargrove, et al., 1989; Islam and Weil, 2000-b; Min, et al., 2003; Tester, 1990; Werner, 1997). Likewise Chikowo, et al. (2004) reported that incorporation of woody legumes into the soil reduces bulk density and increases soil granulation and porosity. The positive effect of $\mathrm{P}$ application in increasing biomass production of legumes has been widely reported (Azad, et al., 1988; Bhadoria, et al., 2004; Hundal and Biswas, 1988; Nayyar and Chhibba, 2000; Ogoke, et al.,2004). The overall increase in biomass production is attributed to increases in $\mathrm{P}$ application that in turn triggers better root development and thereby increase nutrient absorbtion. It may be inferred that legume crops without P may, however, suffer from nitrogen deficiency resulting in reduced biomass production. Malik, et al. (2002) reported that highest fresh biomass production of rice bean was found at $90 \mathrm{~kg} \mathrm{P} / \mathrm{ha}$. These results suggest that higher doses of $\mathrm{P}$ appear to produce maximum biomass production in this region. Significant differences in volume fraction of pore space suggest that sesbania amended soil pore space is much higher than other treatments on a volume basis. It means there was a range of pore size in soils under different green manures 
Evaluation of soil physical properties as influenced by various green ...

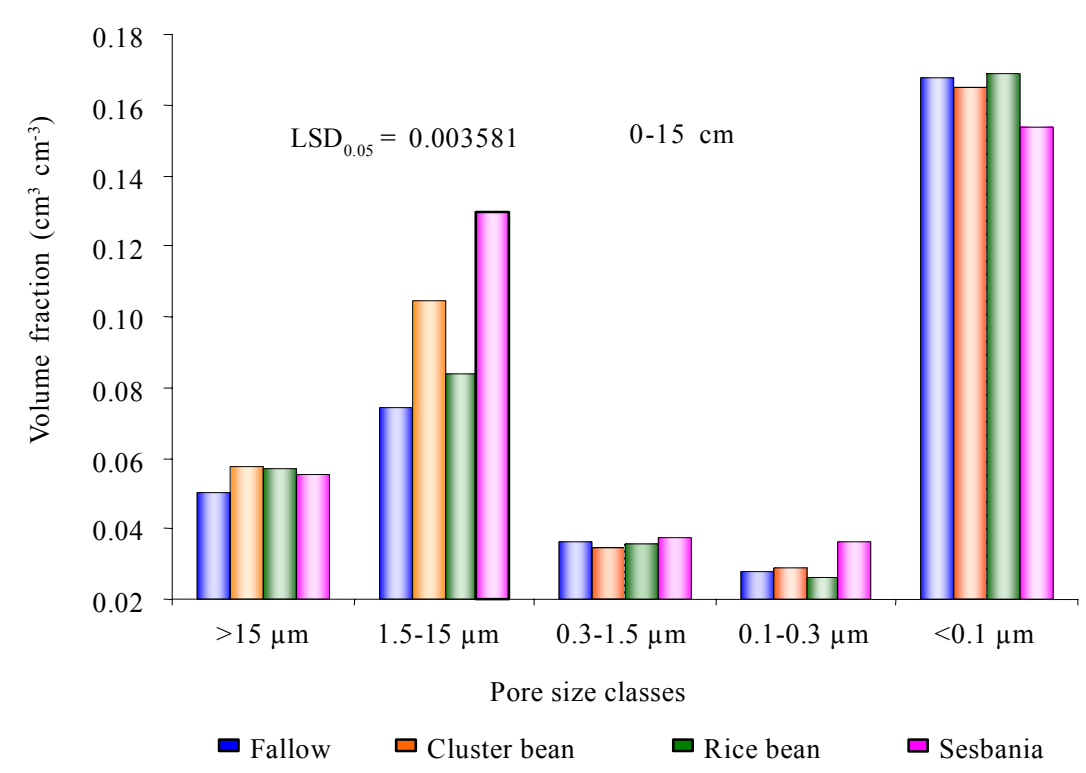

Fig. 7-a: Effect of green manuring legumes and P-fertilization on pore size distribution in soil $(0-15 \mathrm{~cm})$

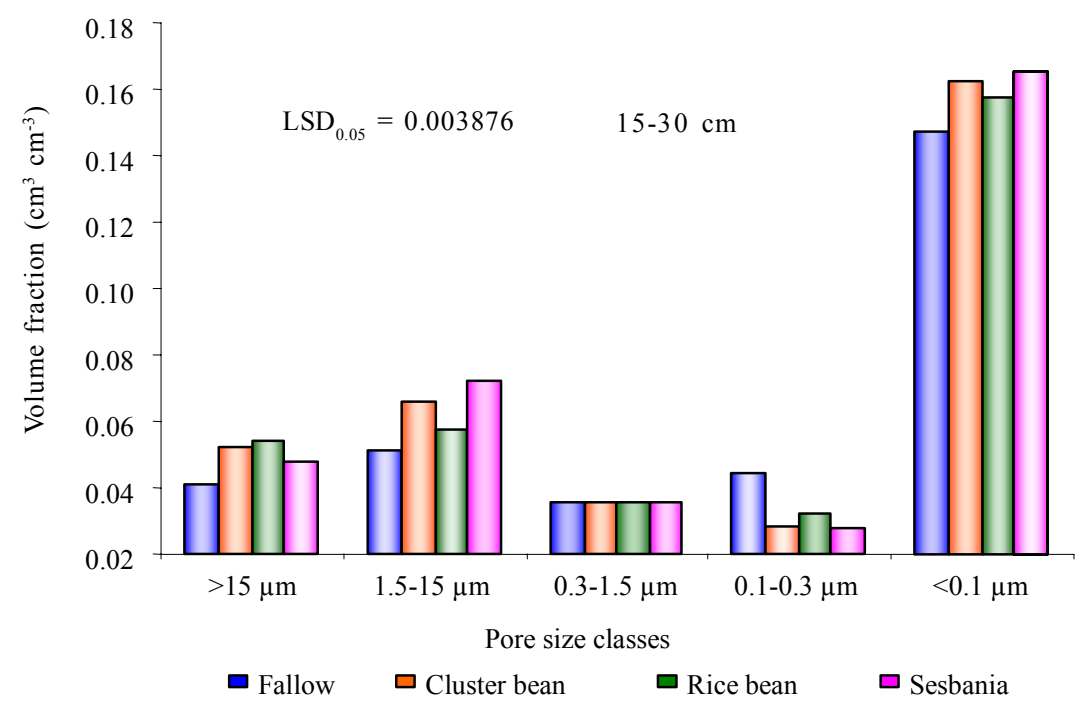

Fig. 7-b: Effect of green manuring legumes and P-fertilization on pore size distribution in soil $(15-30 \mathrm{~cm})$

Those in turn are related to pore size distribution and continuity. This is very important for the air and water balance of soil since aeration critically depends upon pore size distribution (Aon, et al., 2001). Increased total porosity of soils under sesbania suggests that sesbania is able to increase larger pores and the soil is far more likely to be regulated by macropores over micropores. Sesbania exhibited greater soil pore space in 1.5 to 15 $\mu \mathrm{m}$ radius range that should retain plant-available water.
Pores with diameters between 0.1 and $15 \mu \mathrm{m}$ are assumed to retain more plant available water than larger pores (Azooz, et al., 1996; Hill and Meza-Montalvo, 1990). The use of sesbania as green manure consistently increased macro and mesopores, and maintained micropores continuity undisturbed, which consequently resulted in greater plant available water holding capacity. Changes in pore network could result in changes in the storage and transmission of water, 
which in turn may lead to improved crop performance (Barzegar, et al., 2003). A significant increase in volumetric moisture content supported our results that the soil under sesbania had more porosity with a pore size distribution shifted toward macropores from micropores compared to the soils under other treatments. It may be concluded from the field study that green manuring leguminous crops (sesbania, rice bean and cluster bean), reduced soil bulk density (5\%), enhanced total porosity (8\%), and macropores and large mesopores (28\%). Maximum reduction (7\%) in soil bulk density, and an increase $(11 \%)$ in total soil porosity and available water $(17 \%)$ was observed in plots where sesbania was incorporated as green manuring crop. The order of effectiveness in improving bulk density, macro and mesopores was sesbania > cluster bean $>$ rice bean. Sesbania produced greater number of macro and large mesopores about $41 \%$ increased over control followed by cluster bean (29\%) and rice bean (16\%). Phosphorus application showed meager positive impact on various soil physical properties. However, this did not have any significant effect on increasing porosity or reducing bulk density of soil. Significant differences in volume fraction in pore space suggest that pore space on a volume basis was much higher in sesbania-amended soil than in other treatments.

\section{REFERENCES}

Aon, M.A., Sarena, D.E., Burgos, J.L., Cortassa, S., (2001). Microbiological, chemical and physical properties of soils subjected to conventional or no-till management: an assessment of their quality status. Soil Till. Res., 60, 173186.

Azad, M.I., Javed, A.S., Dogar, M.S., (1988). Effect of Rhizobium japonicum, phosphorus and iron on grain yield, protein content and N-fixation by soybean. Pak. J. Soil. Sci., 3, 31-33.

Azooz, R.H., Arshad, M.A., Franzlucbbers, A.J., (1996). Pore size distribution and hydraulic conductivity affected by tillage in Northwestern Canada. Soil Sci. Soc. Amer. J., 60, $1197-$ 1201 .

Barzegar, A.R., Asoodar, M.A., Khadish, A., Hashemi, A.M., Herbert, S.J., (2003). Soil physical characteristics and chickpea yield responses to tillage treatment. Soil Till. Res. 71, 48-57.

Bhadoria, P.S., El Dessougi, H., Liebersbach, H., Claassen, H., (2004). Phosphorus uptake kinetics, size of root system and growth of maize and groundnut in solution culture. Plant Soil, 262, 327-336.

Black, G.R., Hartge, K.H., (1986). Bulk density. In: A. Klute (Ed.). Methods of Soil Analysis. Part I. Physical and Mineralogical Methods. 2 ${ }^{\text {nd. }}$ Ed., Agronomy No. 9 (part I). ASA-SSSA. Madison, Wisconsin, USA, 363-375.
Carlsson, G., Huss-Danell, K., (2003). Nitrogen fixation in perennial forage legumes in the field. Plant Soil, 253, 353372 .

Chikowo, R., Mapfumo, M., Nyamugafat, P., Giller, K.E., (2004). Woody legume fallow productivity, biological nitrogen fixation and residual benefits to two successive maize crops in Zimbabwe. Plant Soil, 262, 303-315.

Ekwue, E.I., (1990). Organic matter effects on soil strength properties. Soil Till. Res., 16, 289-297.

Goldhamer, D.A., Grimes, D.W., Culick, S.H., Munk, D. S., (1994). Cover-cropped enhanced water infiltration of a slowly permeable fine sandy loam. Soil Sci. Soc. Amer. J., 58, 1539-1546.

Gupta, S.C., Larson, W.E., (1979). Estimating soil water retention characteristics from particle size distribution, organic matter percent and bulk density. Wat. Res., Research, 1633-1635.

Hargrove, W.L., McVay, K.A., Radcliff, D.F., (1989). Winter legume effects on soil properties and nitrogen fertilizer requirements. Soil Sci. Soc. Amer. J., 53,1856-1862.

Haynes, R.J., (2000). Interactions between soil organic matter status, cropping history, method of quantification and sample pretreatment and their effects on measured aggregate stability. Biol. Fertil. Soils 30: 270-275.

Hill, R.L., Cruse, R.M., (1985). Tillage effects on bulk density and soil strength of two Mollisols. Soil Sci. Soc. Amer. J., 49,1270-1273.

Hill, R.L., Meza-Montalvo, M., (1990). Long-term wheel traffic effects on soil physical properties under different tillage systems. Soil Sci. Soc. Amer. J., 54, 865-870.

Hundal, H.S., Biswas, A.C., (1988). Phosphorus sorption characteristics of flooded soil amended with green manure. Trop. Agric. (Trinidad), 65, 185-187.

Islam, K.R., Weil, R.R., (2000a). Soil quality indicator properties in mid-Atlantic soils as influenced by conservation management. J. Soil Water Conser., 55, 69-78.

Islam, K.R., Weil, R.R. (2000b). Land use effects on soil quality in a tropical forest ecosystem of Bangladesh. Agric. Ecosyt. Environ., 79, 9-16.

Klute, A., (1986(. Water retention: laboratory methods. In: A. Klute (Ed.). Methods of Soil Analysis. Part I. Physical and Mineralogical Methods. 2nd ed., Agronomy No. 9 (part I). ASA-SSSA. Madison, Wisconsin, USA, 635-662.

Lampurlanes, J., Cantero-Martinez, C., (2003). Soil bulk density and penetration resistance under different tillage and crop management systems and their relationship with barley root growth. Agron. J., 95, 526-536.

Malik, M.A., Saleem, M.F., Cheema, M.A., (2002). Substitution of nitrogen requirement of wheat (Triticum aestivum L.) through green manuring. Int. J. Agric. Biol., 4, 145-147.

Mayer, J., Buegger, F., Jensen, E.S., Schloter, M., (2003). Residual nitrogen contribution from grain legumes to succeeding wheat and rape and related microbial process. Plant Soil, 255, 541-554.

McRae, R.J., Mehuys, G.R., (1988). The effect of green manuring on the physical properties of temperate-area soils. Adv. Soil Sci., 3, 71-94.

Min, D.H., Islam, K.R., Vough, L.R., Weil, R.R., (2003). Dairy manure effects on soil quality properties and carbon sequestration in alfalfa-orchard-grass systems. Commun. Soil Sci. Plant Anal., 34, 781-799. 
Nayyar, V.K., Chhibba, I.M., (2000). Effect of green manuring on micro-nutrient availability in rice-wheat cropping system of Northwest India. In: I. P. Abrol, Bronson, K.F., Duxbury, J.M., Gupta, R.K., (Eds.). Long-term Soil Fertility Experiments in Rice-Wheat Cropping Systems. Rice-Wheat Consortium Paper Series 6. New Delhi, India.

Nelson, D.W., Sommers, L.E., (1980). Determination of total nitrogen in plant material. Agron. J., 65, 109-112.

Ogoke, I.J., Togun, A.O., Carsky, R.J., Dashiell, K., (2004). Effect of phosphorus fertilizer on soya bean residue turnover in the tropical moist savanna. J. Agron. Crop. Sci., 190, 367-373.
Scott, H.D., Mauromoustakos, A., Handayni, I.P., Miller, D.M., (1994). Temporal variability of selected properties of Loessial soil as affected by cropping. Soil Sci. Soc. Amer. J., 58, $1531-1538$.

Tester, C.F., (1990). Organic amendment effects on physical and chemical properties of a sandy soil. Soil Sci. Soc. Amer. J., 54, 827-831.

Werner, M.R., (1997). Soil quality characteristics during conversion on organic orchard management. Appl. Soil Ecol., 5, 151-167.

\section{AUTHOR (S) BIOSKETCHES}

Sultani, M.I., M.Sc., Ph.D. is coordinator, Rangeland Program, Institute of Natural Resources and Environmental Sciences, National Agricultural Research Center, Islamabad, Pakistan. Dr. Sultani is currently on an assignment as a Project Director, R \& S, NARS-B, Quetta, Pakistan. Email: mail@rri.isb.sdnpk.org

Gill, M.A., M.Sc. is senior scientific officer, Rangeland Program, Institute of Natural Resources and Environmental Sciences, National Agricultural Research Center, Islamabad, Pakistan.

Anwar, M.M., M.S. (Hons.), Ph.D. is senior scientific officer, Rangeland Program, Institute of Natural Resources and Environmental Sciences, National Agricultural Research Center, Islamabad, Pakistan.

Athar, M., M.Sc., M.Phil., Ph.D., D.Sc. is research scientist with California Department of Food and Agriculture, Sacramento, California, USA. Email: atariq@cdfa.ca.gov

\section{This article should be referenced as follows:}

Sultani, M.I., Gill, M.A., Anwar, M.M., Athar, M., (2007). Evaluation of soil physical properties as influenced by various green manuring legumes and phosphorus fertilization under rainfed conditions, Int. J. Environ. Sci. Tech., 4 (1), 109-118. 